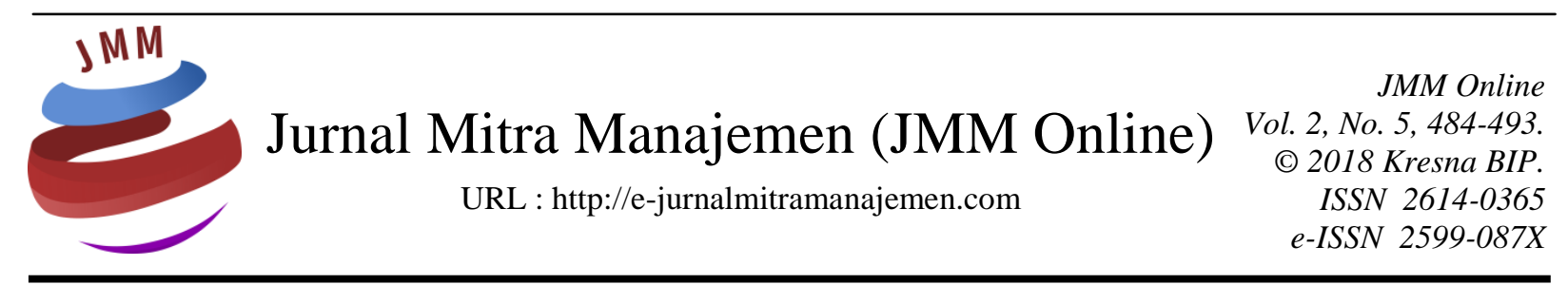

\title{
IMPLEMENTASI FUNGSI KEPEMIMPINAN KEPALA MADRASAH DI MTs MAFATIKHUL HUDA JAGASIMA
}

\author{
Afif Nur Asafu \\ UIN Sunan Kalijaga Yogyakarta
}

INFORMASI ARTIKEL

Dikirim : 03 September 2018

Revisi pertama : 10 September 2018

Diterima : 11 September 2018

Tersedia online : 28 September 2018

Kata Kunci : Implementasi, Fungsi Kepemimpinan, Kepala Madrasah

Email : afifnur76@gmail.com

\section{ABSTRAK}

Tujuan penelitian ini adalah untuk menganalisi dan mengkaji secara deskriftif mengenai implementasi fungsi kepemimpinan kepala madrasah di MTs Mafatikhul Huda Jagasima. Teknik pengumpulan data dalam penelitian ini adalah observasi, wawancara, dan dokumentasi, Sedangkan Teknik analisis data dalam penelitian ini dilakukan berdasarkan analisis deskriptif, sebagaimana yang dikembangkan oleh miles dan huberman mengemukakan bahwa aktifitas dalam analisis data, yaitu data reduction, data display, dan conclusion drawing / verification. Sumber informan dalam penelitian ini adalah, Kepala Madrasah, Wakil Kepala Madrasah, Kepala Tata Usaha, Wakil Kepala Tata Usaha, Guru-guru serta karyawan MTs Mafatikhul Huda Jagasima. Berdasarkan hasil penelitian yang didapat bisa dikatakan bahwa kepala madrasah MTs Mafatikhul Huda Jagasima, mengerti dan memahami tentang fungsi kepemimpinan hal tersebut dibuktikann dari cara beliau dalam menjalankan roda kepemimpinan, dari hasil penelitian dapat simpulkan bahwa dalam menjalankan roda kepemimpinannya kepala madrasah MTs Mafatikhul Huda menjalankan fungsi kepemimpinannya yaitu fungsi konsultatif, fungsi partisipasi dan fungsi pengendalian. 


\section{PENDAHULUAN \\ Latar Belakang}

Kepemimpinan merupakan salah satu hal yang sangat vital yang harus ada disebuah organisasi. Maju mundurnya sebuah organisasi itu bisa dikatakan tergantung pemimpinnya, karena tugas dari seorang pemimpin adalah menjadi motor penggerak. Agar dapat menjalankan fungsi kepemimpinan dengan baik seorang kepala madrasah dituntut untuk bisa memahami dan mengerti serta mampu mengimplementasikan fungsi-fungsi kepemimpinannya dalam rangka pencapaian visi dan misi sebuah organisasi yang dipimpinnya. Pemimpin memiliki pengaruh terhadap lembaga yang dipimpinnya dalam menghadapi berbagai tantangan yang muncul. Pemimpin memegang peran kunci dalam memformulasikan strategi organisasi, sehingga perannya akan mempengaruhi keberhasilan organisasi atau lembaga, dengan demikian pemimpin dituntut bekerja secara optimal, komunikatif cerdas, amanah jujur, dan dapat mempengaruhi bawahannya sehingga akan menciptakan pemimpin yang berwibawa, tegas, adil dan bijaksana serta dicintai oleh pengikutnya. Ketika seorang pemimpin memiliki kemampuan-kemampuan yang layaknya dimiliki oleh seorang pemimpin seperti kemampuan manajerial, kemampuan mengarahkan, kemampuan memotivasi dan lain-lain. Maka diharapkan pemimpin tersebut mampu merangkul semua elemen yang ada di madrasah dalam rangka pencapaian tujuan madrasah. Di MTs Mafatikhul Huda Jagasima menjadi menarik untuk diteliti dengan alasan Kepala Madrasah MTs Mafatikhul Huda Jagasima bukan dari lulusan manajemen pendidikan, akan tetapi beliau tetap mampu memimpin dan bertahan sampai saat ini, disisi lain beliau juga mampu menggerakan para guru guna menjalankan tugas dan fungsinya dalam rangka pencapaian visi dan misi madrasah. Walaupun disisi lain mutu pendidikan di MTs Mafatikhul Huda Jagasima bisa dikatakan masih belum terlalu baik, hal tersebut dibuktikan dengan masih kurangnya minat para siswa lulusan sekolah dasar untuk masuk atau mendaftar di MTs Mafatikhul Huda Jagasima.

\section{Rumusan Masalah}

Salah satu permasalahan yang terjadi dalam sebuah lembaga pendidikan adalah Kurangnya kemampuan seorang pemimpin dalam rangka menjalankan roda kepemimpinannya hal tersebut menyebabkan kurang maksimalnya sebuah fungsi dari kepemimpinan

\section{Tujuan Penelitian}

Untuk mengetahui tentang fungsi kepemimpinan kepala madrasah di MTs Mafatikhul Huda Jagasima, penelitian ini dilakukan dengan cara melihat perilaku kepala madrasah dalam menjalankan roda kepemimpinannya.

\section{KAJIAN PUSTAKA \\ Fungsi-Fungsi Kepemimpinan}

Hadari Nawawi dan M. Martini Hadari, (2012: 80) Fungsi kepemimpinan di bagi menjadi lima. Kelima fungsi kepemimpinan itu adalah: 


\section{Fungsi Instruktif}

Fungsi ini berlangsung dan bersifat komunikasi satu arah. Pemimpin sebagi pengambil keputusan berfungsi memerintahkan pelaksanaannya pada orang-orang yang dipimpin. Pemimpin sebagai komunikator merupakan pihak yang menentukan apa (isi perintah), bagaimana (cara mengerjakan perintah), bilamana (waktu memulai, melaksanakan dan melaporkan hasilnya) dan dimana (tempat mengerjakan perintah) agar keputusan dapat diwujudkan secara efektif. Fungsi orang yang dipimpin (anggota kelompok/organisasi) hanya lah melaksanakan perintah. Inisiatif tentang segala sesuatu yang ada kaitannya dengan perintah itu, sepenuhnya merupakan fungsi pemimpin.

2. Fungsi Konsultatif

Fungsi ini berlangsung dan bersifat komunikasi dua arah, meskipun meskipun pelaksanaannya sangat tergantung pada pihak pemimpin. Pada tahap pertama dalam usaha menentukan keputusan, pemimpin kerap kali memerlukan bahan pertimbangan, yang megharuskannya berkonsultasi dengan orang-orang yang dipimpinnya. Konsultasi ini dapat dilakukannya secara terbatas hanya dengan orangorang tertentu saja, yang dinilainya mempunyai berbagai bahan informasi yang diperlukannya dalam menetapkan keputusan. Disamping itu mungkin pula konsultasi itu dilakukannya untuk mendengarkan pendapat dan saran, apabila suatu keputusan yang direncanakannya ditetapkan. Selanjutnya konsultasi dapat pula dilakukan secara meluas melalui pertemuan dengan sebagian besar atau semua anggota kelompok/organisasinya. Konsultasi seperti itu dilakukan apabila keputusan yang akan ditetapkan sifatnya sangat prinsipil (penting), baik bagi kelompok/organisasi maupun sebagian besar/seluruh anggotanya. Tahap berikutnya konsultasi dari pimpinan pada orang-orang yang dipimpin dapat dilakukan setelah keputusan ditetapkan dan sedang dalam pelaksanaan. Konsultasi itu dimaksudkan untuk memperoleh masukan berupa umpan balik (feedback), yang dapat dipergunakan untuk memperbaiki dan menyempurnakan keputusan-keputusan yang telah ditetapkan dan dilaksanakan. Konsultasi dapat dilakukan secara terbatas atau diperluas, sebagaimana telah diutarakan diatas. Dengan menjalankan fungsi konsultatif dapat diharapkan keputusan-keputusan pimpinan, akan mendapat dukungan dan lebih mudah mengintruksikannya. Sehingga kepemimpinan berlangsung efekif. Fungsi konsultatif ini menharuskan pimpinan belajar menjadi pendengar yang baik, yang biasanya tidak mudah melaksanankannya, mengingat pimpinan lebih banyak menjalankan peranan sebagai pihak yang didengarkan. Untuk itu pemimpin harus meyakinkan dirinya bahwa dari siapapun juga mungkin diperoleh gagasan, aspirasi, saran dan pendapat yang konstruktif bagi pengembangan kepemimpinannya.

3. Fungsi Partisipasi

Fungsi ini tidak sekedar berlangsung dan bersifat dua arah, tetapi juga berwujud pelaksanasn hubungan manusia yang efektif, antara pemimpin dengan dan sesama orang yang dipimpin. Dalam menjalankan fungsi ini pemimpin berusaha mengaktifkan orang-orang yang dipimpinnya, baik dalam keikutsertaan mengambil keputusan maupun dalam melaksanakannya. Setiap anggota kelompok memperoleh kesempatan yang sama untuk berpartisipasi dalam melaksanakan kegiatan yang 
dijabarkan dari tugas-tugas pokok, sesuai dengan posisi/jabatan masing-masing. Partisipasi tidak berarti bebas berbuat semuanya, tetapi dilakukan secara terkendali dan terarah berupa kerjasama dengan tidak mencampuri atau mengambil tugas pokok yang lain. Fungsi partisipasi hanya mungkin terwujud jika pemimpin mengembangkan komunikasi yang memungkinkan terjadinya pertukaran pendapat, gagasan dan pandangan dalam memecahkan masalah-masalah. Yang bagi pimpinan akan dapat dimanfaatkan untuk mengambil keputusan-keputusan. Dari sisi lain fungsi partisipasi berarti juga kesediaan pemimpin untuk tidak berpangku tangan pada saat orang-orang yang dipimpin melaksanakan keputusannya. Pemimpin tidak boleh sekedar mampu membuat keputusan dan memerintahkan pelaksanaannya, tetapi juga ikut dalam proses pelaksanaannya, dalam batas-batas tidak menggeser dan mengganti petugas yang bertanggung jawab melaksanakannya. Keikutsertaan pemimpin harus tetap dalam fungsi sebagai pemimpin dan bukan pelaksana.

4. Fungsi Delegasi

Fungsi ini dilaksanakan dengan memberikan pelimpahan wewenang membuat/menetapkan keputusan, baik melalui persetujuan maupun tanpa persetujuaan dari pimpinan. Fungsi ini mengharuskan pemimpin memilah-milah tugas pokok organisasinya dan mengevaluasi yang dapat dan tidak dapat dilimpahkan pada orang-orang yang dipercayainya. Fungsi delegasi pada dasarnya berarti kepercayaan. Pemimpin harus bersedia dan dapat mempercayai oranglain, sesuai dengan posisi/jabatannya, apabila diberi/mendapat pelimpahan wewenang. Sedang penerima delegasi harus mampu memelihara kepercayaan itu, dengan melksanakannya secara bertanggung jawab. Fungsi pendelegasian harus diwujudkan seorang pemimpin karena kemajuan dan perkembangan kelompok/organisasinya tidak mungkin diwujudkannya sendiri. Pemimpin seorang diri tidak akan dapat berbuat banyak dan bahkan mungkinb tidak ada artinya sama sekali. Oleh karena itu sebagian wewenangnya perlu didelegasikan pada para pembantunya, agar dapat dilaksanakan secara efektif dan efisien.Sehubungan dengan itu musyawarah dan konsultasi ikut berperan, terutama untuk memberikan kesempatam bagi para penerima delegasi, agar selalu berorientasi pada kebijaksanaan umum dari pimpinan. Disamping itu musyawarah dan konsultasi penting artinya bagi penerima delegasi, apabila harus membuat keputusaan yang bersifat prinsipiil. Keputusan-keputusan seperti itu sebelum ditetapkan tidak boleh tidak, harus di konsultasikan, guna memperoleh petunjuk dan pengarahan pimpinan.

5. Fungsi Pengendalian

Fungsi ini cenderung bersifat komunikasi satu arah, meskipun tidak mustahil untuk dilakukan dengan cara komunikasi dua arah. Fungsi pengendalian bermaksud bahwa kepemimpinan yang sukses/efektif mampu mengatur anggotanya secara terarah dalam koordinasi yang efektif, sehingga memungkinkan tercapainnya tujuan bersama secara maksimal. Sehubungan dengan itu berarti fungsi pengendalian dapat diwujudkan melalui kegiatan, bimbingan pengarahan, koordinasi, dan pengawasan. Dalam kegiatan tersebut pemimpin harus aktif, namun tidak mustahil untuk dilakukan dengan mengikutsertakan anggota kelompok/organisasinya.Bimbingan dan pengarahan yang dilakukan selama kegiatan kelompok/organisasi berlangsung pada dasarnya bersifat pengawasan preventif. Dengan melakukan kegiatan tersebut 
berarti pemimpin berusaha mencegah terjadinya kekeliruan atau kesalahan setiap unit atau perseorangan dalam melaksanakan volume dan beban kerjanya atau perintah dari pimpinannya. Kegiatannya dilakukan dengan cara meluruskan setiap penyimpangan, agar secara terus menerus terarah pada tujuan. Pengendalian dilakukan dengan cara mencegah anggota berfikir dan berbuat sesuatu yang cenderung merugikan kepentingan bersama/organisasi. Oleh karena itu sifatnya tidak boleh kaku, karena tidak mustahil dari anggota ditemukan sesuatu yang positif dan dapat meningkatkan efesiensi dan efektivitas pencapaian tujuan.Koordinasi sebagai kegiatan pengendalian dalam kepemimpinan bermaksud mewujudkan pelaksanaan kegiatan saling menunjang dan saling isi-mengisi, antar setiap unit atau secara perseorangan. Koordinasi bermaksud mencegah suatu kegiatan dikerjakan oleh banyak unit atau perseorangan secara terpisah, sedang kegiatan lain tidak ada atau terlalu sedikit anggota yang mengerjakannya. Dengan koordinasi diharapkan terwujud kerjasama yang harmonis antar unit tau perseorangan dalam melaksanakan kegiatan yang memerlukan kebersamaan. Fungsi pengendalian harus meluruskan porsi kegiatan masing- masing dan porsi mana yang memerlukan kerja sama. Dengan demikian tidak akan terjadi tumpang tindih pelaksanaan kegiatan, yang akan memberi dampak meningkatnya efisiensi dan efektivitas usaha pencapaian tujuan kelompok/organisasi. Fungsi pengendalian selanjutnya dilaksanakan melalui kegiatan pengawasan (kontrol) terhadap pelaksanan volume dan beban kerja atau perintah pimpinan. Pengawasan dapat dilakukan sebagai kegiatan preventif. Disamping itu pengawasan dapat juga dilakukan sebagai kegiatan kuratif, yang bertujuan untuk memperbaiki dan menyempurnakan kekeliruan atau kesalahan yang sudah terjadi. Pengawasan kuratif dilakukan setelah kegiatan selesai dilaksanakan, baik berupa pengawasan langsung maupun tidak langsung. Dalam kegiatan administrasi pengawasan yang dilakukan oleh pimpinan atau oleh petugas yang di tunjuk dilingkungan organisasi sendiri, disebut pengawasan intern. Sedang yang dilakukan oleh petugas pengawasan dari suatu badan tertentu diluar organisasi yang diawasi, disebut pengawasan ekstern. Pengawasan intern sebagai fungsi kepemimpinan disebut juga pengawasan melekat. Dengan kata lain pengawasan dilakukan karena merupakan bagian dari volume kerja seorang pemimpin. Bilamana disebutkan secara spesifik, pengawasan melekat pada fungsi kepemimpinan, sehingga memungkinkannya melakukan pengendalian terhadap kegiatan anggota kelompok/organisasinya. Pengawasan dapat dilakukan secara langsung dan tidak langsung. Pengawasan langsung dilakukan dengan cara pemeriksaan dan pemantauan terhadap kegiatan anggota yang sedang berlangsung, yang dilaksanakan oleh pemimpin itu sendiri. Pengawasan tidak langsung dilakukan pemimpin dari jarak jauh, melalui laporan-laporan yang disampaikan anggota dalam melaksanakan tugas-tugas pokoknya atau perintah pimpinannya

\section{METODE PENELITIAN}

\section{Waktu dan Subyek Penelitian}

Waktu dalam penelitian ini adalah dari bulan Mei sampai Agustus 2018, sedangkan subyek dalam penelitian ini Implementasi fungsi-fungsi Kepemimpinan di MTs Mafatikhul Huda Jagasima Klirong Kebumen. 


\section{Jenis Penelitian}

Jenis penelitian ini adalah jenis penelitian lapangan. Penelitian ini menggunakan pendekatan kualitatif dengan menggunakan metode deskriptif. Penelitian ini digunakan untuk mengkaji permasalahan dan memperoleh makna secara mendalam tentang fungsi kepemimpinan kepala madrasah di MTs Mafatikhul Huda Jagasima Klirong Kebumen. Bogdan dan Taylor seperti yang dikutip Moeleong (2010: 3) mengatakan bahwa metodologi kualitatif merupakan prosedur penelitian yang menghasilkan data deskriptif berupa kata-kata tertulis maupun lisan dan orang-orang yang diamati.

\section{Teknik Pengumpulan Data}

Penelitian ini adalah penenlitian lapangan yang bersifat deskriptif kualitatif, maka teknik pengumpulan data yang digunakan untuk mendukung penelitian ini, adalah:

\section{Observasi}

Emzir (2012:37) Observasi atau pengamatan dapat didefinisikan sebagai perhatian yang terfokus terhadap kejadian, dan gejala. Perhatian terfokus terhadap gejala atau kejadian dengan maksud menafsirkannya, mengungkapkan faktor-faktor penyebabnya dan menemukan kaidah-kaidah yang mengaturnya.Dalam penelitian ini peneliti terjun langsung untuk melihat kevalidatan yang ingin diteliti.

2. Teknik Wawancara

Sugiyono (2013:194) Wawancara digunakan sebagai teknik pengumpulan data apabila peneliti ingin melakukan studi pendahuluan untuk menenukan permasalahan yang harus diteliti, dan juga apabila peneliti ingin mengetahui hal-hal dari responden yang lebih mendalam. Teknik wawancara dalam penelitian ini adalah percakapan dengan maksud tertentu. Percakapan itu dilakukan oleh dua pihak yaitu pewawancara yang mengajukan pertanyaan dan mewawancarai yang memberikan jawaban atas pertanyaan itu

3. Dokumentasi

Elvinaro Ardianto (2011:61) Dokumentasi adalah salah satu teknik pengumpulan data yang digunakan dalam metodologi peneliti sosial untuk menelusuri data historis. Sebagian besar data yang tersedia berbentuk surat catatan harian kenangkenangan dan laporan. Dalam penelitian ini, dokumentasi digunakan peneliti untuk mengumpulkan data-data dengan mengambil dari dokumen yang telah ada.

\section{Teknik Analisis Data}

Syamsuddin dan Mismala (2009: 110) Analisis data adalah proses pelacakan dan pengaturan secara sistematis transkip wawancara, catatan lapangan, dan bahanbahan lain yang dikumpulkan untuk meningkatkan pemahaman terhadap bahan-bahan tersebut agar dapat dipresentasikan semua kepada orang lain. Menganalisis data merupakan langkah penting dalam penelitian, sehingga dapat menarik kesimpulan berdasarkan data yang faktual. Teknik analisis data yang penulis gunakan adalah metode analisis deskriptif bertujuan untuk mendeskripsikan apa-apa yang saat ini berlaku. Mardalis (2008:26) Didalamanya terdapat upaya mendeskripsikan, mencatat, analisis dan menginterpretasikan kondisi-kondisi yang sekarang terjadi atau ada. Sedangkan analisis data dari hasil penelitian ini, dilakukan berdasarkan analisis 
deskriptif, sebagaimana yang dikembangkan oleh miles dan huberman dalam Sugiyono (2013:334) mengemukakan bahwa aktifitas dalam analisis data, yaitu data reduction, data display dan conclusion drawing/verification.

1. Data Reduksi (data reduction)

Reduksi data merupakan suatu bentuk analisis yang menggolongkan, mengarahkan dan mengorganisasi data sedemikian rupa sehingga dapat ditarik kesimpulan data verifikasi. Data yang diperoleh dilapangan jumlahnya cukup banyak, untuk itu perlu dicatat secara teliti dan rinci. Seperti setelah dikemukakan, makin lama penelitian ke lapangan, maka jumlah data akan makin banyak, kompleks, dan rumit.

Dengan kata lain, reduksi data yaitu proses pemilahan atau pemilihan, pemusatan, perhatian pada penyederhanaan data-data yang diperoleh selama peneliti melakukan penelitian di MTs Mafatikhul Huda Jagasima Klirong Kebumen

2. Penyajian Data (data display)

Penyajian data disini dibatasi sebagai sekumpulan informasi yang memberi kemungkinan adanya penarikan kesimpulan dan pengambilan tindakan. Melalui penyajian data tersebut, data terorganisasikan, tersusun dalam pola hubungan, sehingga akan semakin mudah dipahami. Dalam penelitian kualitatif, penyajian data bisa dilakukan dalam bentuk uraian singkat, bagan, hubungan antara kategori, flowchart dan sejenisnya.

3. Triangulasi

Triangulasi adalah teknik pemeriksaan keabsahan data yang memanfaatkan sesuatu yang lain diluar data itu untuk keperluan pengecekan atau sebagai pembanding data itu. Denzin membedakan empat macam triangulasi diantaranya dengan memanfaatkan penggunaan sumber, metode, penyidik dan teori. Pada penelitian ini, dari kekempat macam triangulasi tersebut, peneliti hanya menggunakan teknik pemeriksaan dengan memanfaatkan sumber. Triangulasi dengan sumber artinya membandingkan dan mengecek balik derajat kepercayaan suatu informasi yang diperoleh melalui waktu dan alat yang berbeda dalam penelitian kualitatif. Pada teknik triangulasi, yang peneliti lakukan yaitu wawancara dengan kepala Madrasah , wakil kepala madrasah, kepala tata usaha, staf tata usaha dan guru MTs Mafatikhul Huda Jagasima Klirong Kebumen Hasil tersebut lah yang peneliti gunakan untuk membandingkan hasil data yang diperoleh dari wawancara, pengamatan dan dokumen-dokumen yang sudah dikumpulkan dan di cek.

\section{Hasil Penelitian Dan Pembahasan}

Kepala madrasah MTs Mafatikhul Huda adalah Bapak Muhtasimudin, S.Pd.I beliau merupakan alumni salah satu perguruan tinggi swasta di kebumen dengan program studi Pendidikan Agama Islam. Dalam menjalankan roda kepemimpinannya beliau bersikap terbuka, artinya beliau mau menerima segala masukan, kritik, dan juga saran dari seluruh komponen guru dan karyawan MTs Mafatikhul Huda dalam rangka perbaikan dan juga upaya meningkatkan mutu pendidikan di MTs Mafatikhul Huda Jagasima.

Disisi lain ketika ada permasalahan-permasalahan, beliau selaku kepala madrasah selalu menyelsaikan dengan cara bermusyawarah dengan seluruh guru dan 
karyawan, kepala madrasah memberikan peluang yang sama kepada guru dan karyawan untuk memberikan pendapat mengenai permasalahan yang akan diselsaikan. Dan keputusan akhir merupakan keputusan yang di setujui sama-sama atau keputusan bersama. Pengambilan keputusan yang dilakukan oleh kepala madrasah MTs Mafatikhul Huda jagasima adalah dengan cara musyawarah dan mufakat bersama dewan guru dan karyawan. Hampir setiap ada permasalahan yang harus diselasaikan atau keputusan yang harus diambil kepala madrasah selalu mengadakan rapat bersama dewan guru dan karyawan hal tersebut dilakukan dalam rangka bisa mendapatkan keputusan terbaik dan keputusan yang didasari atas persetujuan bersama. Dalam proses pelaksanaan rapat kepala madrasah memberikan peluang yang sama kepada guru dan karyawan agar menyampaikan pendapat dalam rangka penyelsaian permasalahan. Terkadang karena banyaknya pendapat yang diajukan oleh dewan guru dan karyawan dalam sekali rapat belum bisa mengambil sebuah keputusan. Setiap keputusan merupakan sebuah keputusan bersama.

Langkah-langkah Kepala Madrasah MTs Mafatikhul Huda dalam menyelsaikan permasalahan-permasalahan, dalam setiap lembaga pasti ada permasalahanpermaslahan yang harus diselsaikan, di sini kepala madrasah memiliki peran vital dalam rangka menyelsaikan permasalahan yang dihadapi oleh lembaga yang dipimpinnya. Dalam melakukan penyelsaian permasalahan kepala madrasah MTs Mafatikhul Huda Jagasima Klirong Kebumen mengumpulkan informasi mengenai permasalahan yang akan diselesaikan, setelah itu kepala madrasah mengadakan rapat dengan dewan guru dan seluruh staf guna membahas dan menyelsaikan permasalahan yang dihadapi, dalam proses rapat kepala madrasah meminta kepada dewan guru dan staf untuk memberikan tanggapan komentar, maupun pendapat mengenai permasalahan yang akan diselsaikan. Kemudian kepala madrasah menampung berbagai tanggapan, pendapat dan komentar yang sudah diterima, kemudian kepala madrasah memilih salah satu tanggapan, pendapat, atau komentar yang paling tepat, guna menyelsaikan permasalahan. Kemudian kepala madrasah menyampaikan pendapat yang paling tepat kepada dewan guru dan staf yang mengikuti rapat tersebut. Walaupun kepala madrasah sudah memiliki langkah yang tepat untuk menyelsaikan masalah, kepala madrasah tidak akan memutuskan langkah penyelsaian itu sendiri, kepala madrasah tetap menyampaikan kepada dewan guru dan staf yang mengikuti rapat, hal tersebut dilakukan agar keputusan penyelsaian masalah yang diambil merupakan keputusan yang sudah menjadi kesepakatan bersama bukan keputusan penyelsaian masalah yang diambil secara sepihak.

Oleh karena itu terkadang dalam rapat pengambilan keputusan untuk menyelsaikan sebuah permasalahan bisa dilakukan sampai dua atau tiga kali rapat baru bisa diambil sebuah keputusan. Walaupun waktu yang dibutuhkan untuk menyelsaikan sebuah permasalahan cenderung lebih lama, akan tetapi keputusan yang diambil merupakan sebuah kesepakatan bersama, dan telah dirapatkan secara matang dan maksimal. Jika dalam dua atau tiga kali rapat sebuah keputusan untuk penyelsaian sebuah permasalahan belum bisa terselesaikan juga, langkah yang diambil oleh kepala madrasah adalah dengan cara voting, semisal ada dua atau tiga solusi yang sudah ada, maka kepala madrasah melakukan voting, kepala madrasah meminta kepada dewan guru dan staf untuk melakukan voting mengenai langkah penyelsaian masalah. Solusi 
permasalahan yang diambil adalah solusi yang mendapat voting terbanyak. Sebagai contoh dalam penentuan tempat study tour untuk para siswa kelas IX disitu ada beberapa pilihan tempat yang akan dikunjungi, Ketika dirapatkan sebagian guru memiliki perbedaan pendapat mengenai pilihan tempat yang akan dijadikan tempat study tour, hal tersebut terjadi sampai dua kali rapat dan belum terselesaikan akhirnya kepala madrasah melakukan voting mengenai tempat yang akan di jadikan sebagai tempat study tour, voting diberikan kepada dewan guru, staf dan juga seluruh siswa. Hasil voting terbanyak yang menjadi temapt study tour. Dari hasil penelitian diatas membuktikan bahwa kepala madrasah sudah memahami tentang fungsi kepemimpinan, beliau memahami langka-langkah apa saja yang harus dilakukan ketika beliau menjalankan roda kepemimpinannya, disisi lain beliau juga memahami tentang bagaimana cara mnyelsaikan permasalahan-permasalahan yang dihadapi oleh lembaga dan juga bagaimana cara mengambil secara baik dan benar. Kemudian dari langkahlangkah yang digunakan oleh kepala madrasah dalam menjalankan roda kepemimpinan dan dalam menyelsaikan permasalahan-permasalahan yang dihadapi oleh lembaga dapat dikatakan bahwa gaya kepemimpinan yang dipakai oleh kepala madrasah dalam menjalankan roda kepemimpinannya adalah gaya demokratis.

\section{KESIMPULAN DAN SARAN Kesimpulan}

Berdasarkan hasil penelitian yang didapat bisa dikatakan bahwa kepala madrasah MTs Mafatikhul Huda Jagasima, mengerti dan memahami tentang fungsi kepemimpinan hal tersebut dibuktikan dari cara beliau dalam menjalankan roda kepemimpinan, dari hasil penelitian dapat simpulkan bahwa dalam menjalankan roda kepemimpinannya kepala madrasah MTs Mafatikhul Huda menjalankan fungsi kepemimpinannya yaitu fungsi konsultatif, fungsi partisipasi, dan fungsi pengendalian. Disisi lain gaya kepemimpinan yang dipakai oleh kepala madrasah MTs Mafatikhul Huda dilihat dari cara beliau menjalankan roda kepemimpinan, dari cara beliau melakukan penyelsaian permasalahan dan cara beliau melakukan pengambilan sebuah keputusan dapat dikatakan bahwa gaya kepemimpinan kepala madrasah MTs Mafatikhul Huda jagasima Klirong Kebumen adalah gaya kepemimpinan demokratis.

\section{Saran}

Berikut beberapa saran dari penulis:

1. Kepala Madrasah harus berusaha meningkatkan fungsinya sebagai kepala madrasah agar dapat memaksimalkan fungsinya sehingga bisa mencapai tujuan madarasah.

2. Kepala madrasah harus mampu menjaga komunikasi yang sudah terjalin dengan guru dan karyawan.

3. Kepala madrasah harus bisa menjaga hubungan baik yang sudah terjalin dengan guru dan karyawan.

4. Jaga dan pertahankan solidaritas dan hubungan emosional antar civitas akademik, jika semua terkondisi dengan baik maka akan sangat membantu terwujudnya program yang sesuai visi dan misi madrasah.

5. Perlunya koordinasi menyeluruh dan pemberdayaan yang maksimal seluruh guru dan juga staf di MTs Mafatikhul Huda Jagasima Klirong Kebumen. 


\section{DAFTAR PUSTAKA}

Ardianto Elvinaro. 2011. Metodologi Penelitian Public Relations Kuantitatif dan Kualitatif, Cet. 2 Bandung: Remaja Rosdakarya.

Emzir. 2012. Metodologi Penelitian Kualitatif: Analisis Data, Cet. 3 Jakarta:PT Grafindo Persada

Mardalis. 2008. Metode Penelitian Suatu Pendekatan Proposal, Ed. 1. Cet.10. Jakarta: Bumi Aksara.

Lexy J Moleong. 2010. Metodologi Penelitian Kualitatif Bandung: Remaja Rosdakarya.

Nawawi Hadari dan M. Martini Hadari. 2012. Kepemimpinan yang Efektif, Cet. 6 Yogyakarta: Gajah Mada University Press.

Sugiyono. 2013. Metode Penelitian Pendidikan, Cet. 18, Bandung: Alfabeta.

Syamsuddin dan Vismala. 2009. Metode Penelitian Pendidikan Bahasa. Bandung: Remaja Rosdakarya. 